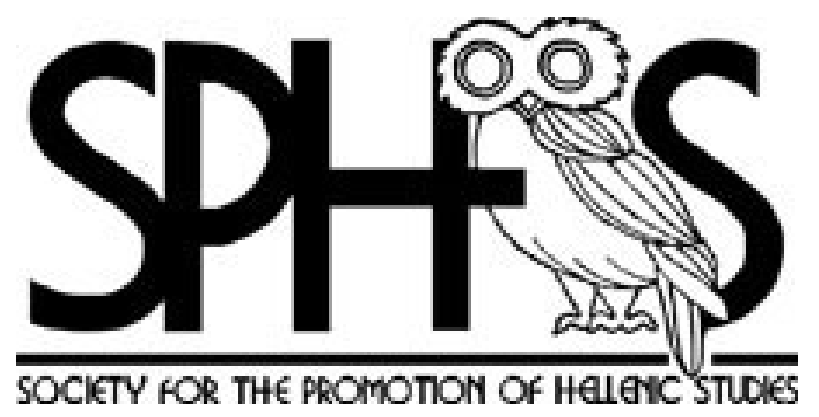

Selected Vase-Fragments from the Acropolis of Athens -- II

Author(s): G. C. Richards

Source: The Journal of Hellenic Studies, Vol. 14 (1894), pp. 186-197

Published by: The Society for the Promotion of Hellenic Studies

Stable URL: http://www.jstor.org/stable/623964

Accessed: 27/12/2014 17:30

Your use of the JSTOR archive indicates your acceptance of the Terms \& Conditions of Use, available at

http://www.jstor.org/page/info/about/policies/terms.jsp

JSTOR is a not-for-profit service that helps scholars, researchers, and students discover, use, and build upon a wide range of content in a trusted digital archive. We use information technology and tools to increase productivity and facilitate new forms of scholarship. For more information about JSTOR, please contact support@jstor.org.

The Society for the Promotion of Hellenic Studies is collaborating with JSTOR to digitize, preserve and extend access to The Journal of Hellenic Studies. 


\section{SELECTED VASE-FRAGMENTS FROM THE ACROPOLIS OF ATHENS.-II.}

THE vase-fragments represented on Plates II.-IV. are with one exception here published for the first time and all belong to red-figured works. For the permission to publish them I am deeply indebted to M. Kavvadias, and I wish also to acknowledge help kindly given me by Dr. Wolters and Mr. Cecil Smith. Three of the works are in the early severe style, one shows the developed severe work and two belong to the advanced fine period. They are distributed on the plates merely with regard to convenience of publication. Nothing is more noticeable to any one glancing over the mass of vase-fragments from the Acropolis than the fact that while the preponderance of black-figured over red-figured works is very great (Dr. Graef puts the proportion at more than three to one), the vast majority of the former are poor in design and carelessly executed but the latter are nearly all careful and good. This seems to show-for the proportion can hardly be due to accident-that the older style continued in favour, probably because it was cheap, long after the introduction of a new method, and that the new school only produced works at the highest level of their ability, and by so doing ultimately commanded the market both at home and abroad. It is not till the second period of red-figured work that careless and hasty productions are turned out. Inferior artists seem to have contented themselves with imitations of successful masters: thus for example one seems to note imitations of Duris in museums.

i.-Pl. II. owing to the interest of its subjects deserves the closest attention. It is a small $\mathrm{kylix}^{1}$ executed with great care, and with an unusually large number of figures in its outside scenes considering the period at which we must place its execution. There is no difficulty of identification. The interior shows the struggle of Peleus and Thetis with slight variations from the ordinary scheme, while $A$ and almost certainly $B$, as Dr. Hartwig has already conjectured, present scenes from the Iliupersis. The interior reminds one strikingly of the Berlin kylix of Peithinos, though

\footnotetext{
1 Dr. Wolters informs me that one fragment of this kylix was found, in August 1886, east of the Parthenon, somewhat deep down, under a layer of poros-fragments, which in all probability contained debris from the Persian devas-

fragments here figured were not noted when found, but fragments of the vase figured on Pl. IV. $a$ were turned up west of the Erechtheion, at the spot where the fourteen archaic statues were discovered all together.
} tation of the Acropolis. The rest of the vase 
there is sufficient difference to prevent the supposition that both are from one hand: but both painters must at any rate have worked from similar designs. Dr. Hartwig, in the chapter of his Meisterschalen ${ }^{2}$ which he devotes to Peithinos, has fully emphasized the archaic and stylized severity of this painter's work and has seen in it a definite tendency opposed to that of the rising naturalistic school. The painter of this kylix aimed rather at a free drawing of the human form, but had not reached the mastery of draughtsmanship which we see in Euphronios, while he had no desire to stylize like Peithinos. The scheme of locked hands in this interior scene may well be contrasted with the same in the cup of Peithinos, as converted into a conventional sort of maeander. Here we see Peleus with bent knee and lowered head, clad in short chiton girt up round the waist, with sheathed sword at his side (the hanger rendered in purple), holding Thetis round the waist and just lifting her off her feet. His name $\Gamma E L E V S$ is laid on in purple. Unfortunately the head is only half preserved and the eye is broken, but it seems to have been rendered by a simple black point. The usual ephebic type is here presented, and the growing beard is rendered with thin 'Firniss.' The hem of the sleeves and neck of the chiton are represented by a triple line. On his back is the conventional and heraldic lion, exactly as in the Peithinos-vase down to the carefully drawn mane. On another fragment are the toes of his right foot and part of the bent leg, on which hangs one coil of a snake. This is more carefully drawn than in the Peithinos-vase. The row of thick dots no doubt is intended to represent the upper side, the small scattered flecks the under side of the creature. Thetis wears a long chiton with stiff parallel folds relieved by the ladder-pattern, which is so common on vases of this period (cp. the Peleus and Thetis frags. of the Acropolis $J a h r b .1888$, Pl. 2, and here p. 191, the Athenodotos-vases J.H.S. x. 1, the Antaios-krater of Euphronios etc.), and a himation with swallow-tail folds, unnaturally spread out on the right. The outline of her bent legs is to be traced beneath the drapery. ${ }^{3}$ The interior field is surrounded by two circular bands of the colour of the clay, and a segment is cut off from the circle by a similar strip, on which rested the right foot of Peleus and probably the right foot of Thetis, at least in part, while her left foot is near to but does not touch the circular band. The smaller fragment is not quite correctly placed in the drawing: it should be shifted a little to the left, so that the base-line of the segment may meet the exterior circle below the left foot of Thetis. As Mr. Cecil Smith has pointed out to me, it is clear from the relative position of the fragments that Thetis is being actually lifted off her feet into the arms of Peleus. The sandal of the left foot does not touch the enclosing circle and is therefore meant to be in the air, and we should restore

\footnotetext{
2 I take the opportunity of hailing the appearance of this great work with delight. Two or three more comprehensive works of the kind accompanied with reliable plates would probably solve nine-tenths of the questions which are debated in connection with Greek

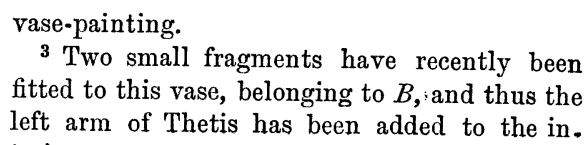

3 Two small fragments have recently been fitted to this vase, belonging to $B$, and thus the left arm of Thetis has been added to the in. terior.
} 
the right foot as touching the ground only slightly with the toes. Hence we get a slight difference of position from that given by Peithinos, who represents Thetis with both her feet flat on the ground, and the advantage is all on the side of our artist. Turning to the exterior fields, a fragment already published (Eph.Arch. 1885, Pl. 5, 3), which corresponds to the smaller fragment of the interior, has long since been rightly interpreted, so far as it goes. The head of Kassandra is unfortunately missing, but the drawing of the fragment seems more severe than that of the similar Vienna fragment published by Hartwig (Arch. Epigr. Mitth. aus Oest. xvi. ii. Fig. 1 a). The nipples are here indicated and the breasts hang in the same direction: the drapery, exactly similar to that of Thetis, conceals what it was difficult to draw correctly. The embroidered robe of the image with its silhouette representations of choruses male and female and its apparently conical shape have been already noted by Dr. M. Mayer and others. It may be added that the lower part of the Palladion in the Vivenzio-vase is less markedly conical, but no doubt the goddess here as there was represented with outstretched spear and shield. Right of Kassandra and somewhat behind the basis of the image is an altar with blood-spots (purple) and in the interval the 'unklare Faltenpartien' (Hartwig), which might possibly belong to the himation of Priam, as it is quite clear from the next fragment to be mentioned that the altar was the seat of the aged king here as elsewhere. But the relative position of the fragments being shown by the inside, it is likely that here as in the Vivenzio-vase sat a female figure, though there is hardly room for two figures as in that work. Next we may restore Priam seated much after the fashion of the scene in the vase of Brygos. On the next fragment we see the right leg of Neoptolemos who is striding to the left. Part of his short chiton, the knob of his sheathed sword, and a greave are visible. Behind are preserved the head and arms of Astyanax 'A $\sigma \tau]$ VANA $[\chi]$ s. Neoptolemos is about to hurl the child at the seated Priam: the child is still alive, the eye being wide open, as in the vase of Euphronios, while Brygos on the other hand represented him as already dead, and in the Vivenzio-vase he lies dead on the lap of his grandfather. It is unfortunate that here, as in the interior of Euphronios' kylix, the figure of Neoptolemos is almost entirely wanting. At this point in our vase there is a great confusion of legs, as on the exterior of Brygos' kylix, parts of two standing and one recumbent man and one standing woman crossing one another. This appearance of confusion is enhanced here by the fact that the circle bounding the exterior scenes on the inside is so small, having a diameter of only $\mathrm{m} \cdot{ }^{\cdot} 084$. Behind the body of Astyanax stands a female figure to right, clad apparently in himation and chiton with hands outstretched towards a warrior, of whom we see the greaved legs, the shield and lowered spear and a part of the chiton, advancing to her. The letter $E$ is in the field between them. There is no motive such as we have in the Brygos-vase, where Akamas leads away Polyxena, or in the Vivenzio-vase where Demophon and Akamas lead away Aithra. Rather the woman is supplicating mercy from one who advances with hostile intent. Noack's restoration of the 
fragmentary exterior of Euphronios' kylix as representing Odysseus and Menelaos pursuing Helen and Aithra is no doubt correct (v. Aus der Anomia), but this is a different scheme. I do not see any other possible view than that this is ELEN]E and the advancing warrior Menelaos; and this view receives support from the remaining figure of the fragment, viz. the recumbent dead warrior, who lies 'en face' in the attitude of the fallen warrior in the Bourguignon kylix (Meisterschalen Pl. X.), which is also that of Eurytion, and Palaisto in the respective vases of Euphronios. The anatomy of the body is almost hidden by the leg and arm which cross it. Blood is pouring from three wounds (purple). The left arm and shoulder rest in the shield, which is half shown. The hair falls in schematic curls on either side of the helmet, which covers the face, though the hair is indicated on the forehead by rows of dots and the eyebrows and the closed eyes with lashes are visible. Long curling appendages to the crest fall down on either side, as in the fallen warrior (Gerhard, Trinkschalen Pl. D). Behind the figure again we see the foot of a man advancing to left. If in the dead man we naturally see Deiphobos, it may be conjectured that this belonged to Odysseus. Before turning to the small fragment which is all that remains of $B,{ }^{4}$ the position of the handles must be ascertained. From the interior one concludes that $A$ contained three groups, and the conclusion is also inevitable that the handle on the one side falls over the warrior who lies dead. If that is so, the extended arm of Kassandra must come under the other handle, and obverse and reverse are thus closely coupled together. Aias must therefore have been the last figure of $B$ on the one side, and on the other the warrior to whom the foot belongs, who has been tentatively named Odysseus. The small separate fragment of $B$ represents a figure with shield, greaves, and short chiton very similar to Menelaos, advancing to left, while the leg is seen of another warrior engaged in combat with an antagonist, whose leg bent at the knee and encased in a greave is seen overlapping the leg of his foe. In this duel then the issue is practically decided. The first-mentioned warrior must have been engaged with an antagonist over the body of a fallen Trojan archer (?) whose trousered leg is visible. The other pair of combatants on the right would be immediately followed by Aias in this case, and we have the following arrangement of $B$ :

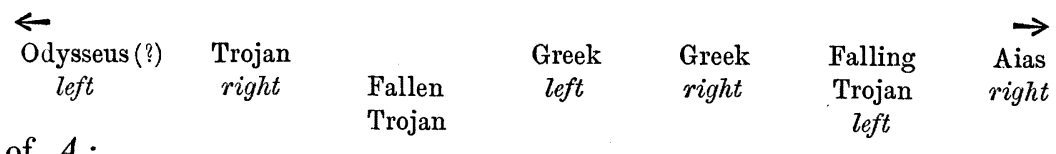

and of $A$ :

$\begin{array}{ccccccc}\text { Kassandra } & \text { Female } & \text { Priam } & \text { Neoptolemos } & \text { Helen } & \text { Menelaos } & \\ \text { Palladion } & \text { figure } & \text { right } & \text { left (Astyanax) } & \text { right } & \text { left } & \text { Fallen } \\ & (?) & & & & & \text { warrior }\end{array}$

\footnotetext{
4 Since writing this, I have heard from Dr. Wolters that two additional fragments of $B$, not here figured, have been added. He writes

'Wir haben zwei Fragmente hinzugefügt,
welche das einzeln gezeichnete Fragment, auf
welchem das Bein eines orientalisch bekleideten
} 
Roughly therefore the number of figures on both sides is the same, but there is no exact correspondence, and the two sides are dovetailed into one another. It would be an unprofitable task to attempt to give names to the combatants of $B$. As to the style of the vase, no doubt Hartwig's estimate of it is correct, that it is a work of the school of Epiktetos. The close

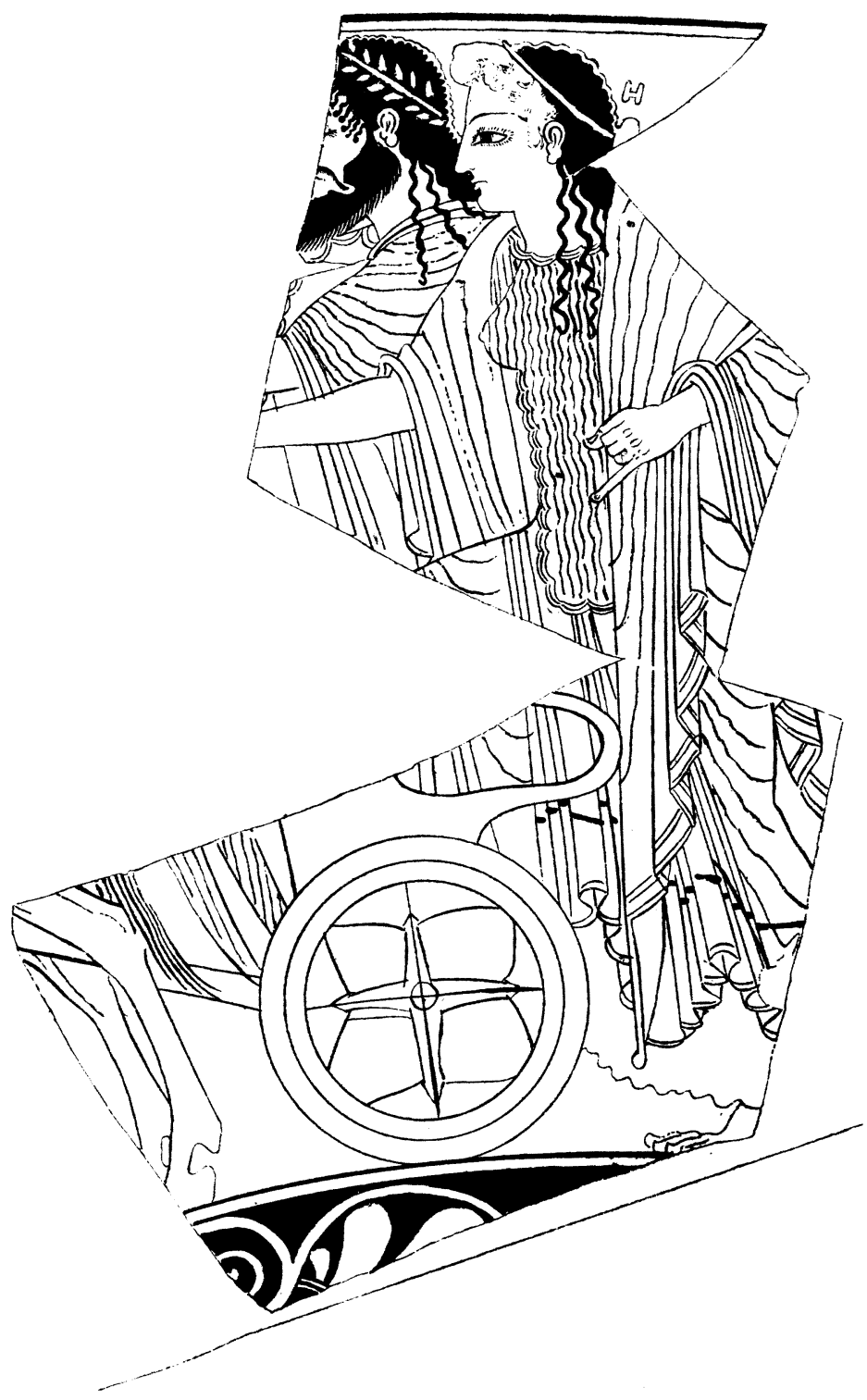

Mannes und die Beine einiger anderen Krieger erscheinen, mit dem Hauptteil der Vase verbinden, und besonders diesen erstgenannten Mann etwas vervollständigen.' A fuller description will show whether I am right in placing two standing warriors on $B$ to the left of this 'fallen Trojan.' Dr. Wolters does not mention any additional inscriptions. 
connection with the b.f. style is shown $(\alpha)$ by the designs on the peplos of the Palladion, $(b)$ by the liberal use of purple, $(c)$ by the absence of palmettes and maeanders under the handles and round the interior, and the use of circles bounding the interior scene, formed by leaving a strip of the clayground. There is nothing except profile-drawing, so far as the feet are concerned, in what we have. The full-face is attempted in the dead warrior but there is practically covered by the helmet. It would seem too venturesome to ascribe the work to any particular master in the present state of our knowledge. It is much to be hoped that Dr. Hartwig will speedily be enabled to do for the school of Epiktetos what he has done for the subsequent vase-painters. I do not think that Chachrylion for instance can be connected with this vase. ${ }^{5}$ It certainly differs very widely from the Vienna fragments, which are nearer to Chachrylion's work than to any other which has yet been recognized. At the same time the rounded treble-line edges of the drapery and the unnatural wave of the himation of Thetis remind one of several of the vases brought together on the first five plates of the Meisterschalen.

ii.-I should like to insert here cuts of parts of the Peleus and Thetis vase from the Acropolis (published incompletely in Jahrbuch 1888, Pl. 2). The two heads, incomplete though one is, are valuable helps towards judging

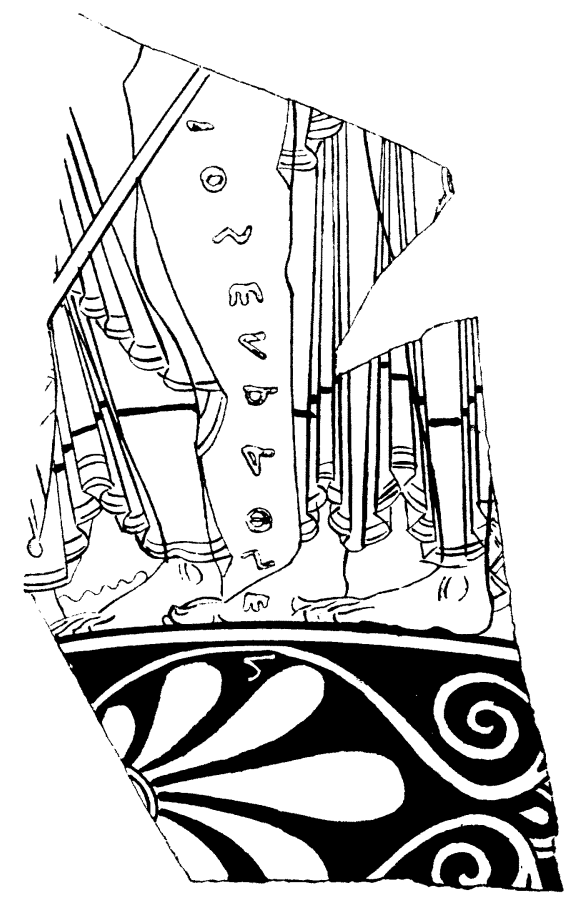

5 Perhaps I may say that the least satisfactory chapter in Hartwig's book seems to me to be the one on Chachrylion. It is difficult to

attribute to one hand the Cambridge signed kylix Pl. II. 3 and the Bourguignon kylix Pl. V. 
of the style of the vase. I am bound to say that they only confirm to my mind Hartwig's view, that this vase is in the style of Peithinos. The head of Hera is just the expressionless type so characteristic of that master. The eye-lashes are carefully indicated as on several figures of the Sosias-vase in Berlin, and with the ornamental separate curls of Zeus one may compare those of Dionysos in that vase. But the inscription remains a standing puzzle. It is as plainly as possibleneighbourhood of the staff could explain a miswriting of | for $N$. The vase cannot however be the work of Euphronios, unless we suppose that the latter painter was so many-sided as to work in two distinct styles according to the nature of his subject.

iii.-Pl. III. 1.-Fragment of a kylix with exploits of Theseus. Unfortunately this appears to be a quite isolated fragment. The kylix was of the older shape derived from the 'Kleinmeister,' with edge setting back at the top, above the outer field. All that is preserved is part of the struggle of Theseus and the Minotaur, which formed a portion of one of the exterior scenes. It may be conjectured with probability that this was not one of a series of scenes, as in the later Theseus vases, but, as in the Epiktetos kylix of the British Museum, it occupied the chief position and was similarly flanked by a female figure to right and left. Theseus, whose face exhibits the older type cormmon to the Epiktetan school, with almond-shaped eye without any attempt at a profile view, with wreath of purple on his head, clad in short girt chiton, the sword-hanger crossing his breast, holds the head of the Minotaur with his left arm, and in his right hand, which is missing, doubtless held the sword and was about to give his antagonist the coup de grâce. The Minotaur's head and chest are preserved, the head covered with double strokes and flecks, though the chest exhibits no such round spots as were introduced by other painters on the analogy of Argos Panoptes (e.g. Duris $A . V$. iii. 234 or the painter of the amphora $A . V$. iii. 160). The head is bent and with his right hand he no doubt grasped at the sword of Theseus, as with Duris, and in his left probably held the stone, which is his usual weapon. The rendering of the anatomy is scanty, the arms of Theseus show no inner drawing, and it is noticeable that even the eyebrow of Theseus, whether by accident or design, is omitted. The same peculiarity, outside of the Epiktetan circle, is to be noted on the fragmentary kylix in the possession of Dr. Hauser (Meisterschalen Pl. XVIII. 1), and within it can be paralleled on the Memnon vases. In the field we read ES, the letters being divided by the head of Theseus. A spot of purple colour at the end of the wreath of Theseus but disconnected with it resembles an 1. It is perfectly correctly rendered in the illustration, but $I$ am convinced that it is not intended to be a letter but rather belongs to the wreath; for otherwise the spacing of the letters would be very peculiar, and in such a position we can only restore either $\Theta] E S\left[\epsilon v^{\prime} s\right]$ or $\left.\epsilon \operatorname{\pi } \pi o^{\prime}\right] E S[\epsilon \nu]$. Which of the two stood there, it is not easy to say. One other letter, in either case $E$, would have occurred in the break above the Minotaur's head. It seems to be most probable that this is a work from the hand of Epiktetos, and it is not in the least an objection to this 
view that we have another similar work from his hand. He seems to have produced a large amount of works from his atelier and the same subject might often be repeated.

iv.-Pl. IV. 1.-Fragments of a red-figured Lutrophoros (Am. Journ. of Arch. 1888, p. 358, Class. Rev. 1888, 188, Klein Lieblingsinschriften, p. 45). This vase was at first called a krater, but since the drawings were made of our two fragments, a great number of others have been added, which when put together make the neck of a large Lutrophoros almost complete; this is decorated with a long procession, of which these two show the one end. The thickness of the clay is considerable. On the larger fragment a bearded man wearing wreath and himation over his left shoulder leaving his right arm and shoulder free is walking to right. In his left raised hand he holds three branches, and his right hand is raised. He is directly followed by two women, the first of whom turns back to converse with her neighbour. Both wear chiton, and himation drawn over the head so as to serve as veil, with stephane, the first also having her head covered by a cap. The first holds in her left the three branches, the second a staff over her shoulder (is it part of a $\sigma \kappa \iota a ́ \delta \epsilon \iota \nu$ ?) : her left hand is upraised in the same attitude as that of the man. The separated fingers are treated in a very lifeless manner and nails are not indicated. Beneath the man's shoulder only four divisions of the 'serratus magnus' are shown.

On the other fragment a youth with fillet, wearing the 'iulus' and draped like the man, also walks to right holding in his left the same three branches. He is separated from the bearded man of the preceding fragment by a figure, whose head is lost. On the left edge of the fragment are two unexplained objects, which I at first supposed to be part of a Nike flying to left. The upper one however is probably not a wing, and the lower might be a piece of drapery. What is the scene represented? The branches ${ }^{6}$ are no doubt intended for the sprinkling of an altar with purificatory water ( $\pi \epsilon \rho \rho-$ $\rho a \nu \tau \eta \dot{p} \iota$ ). A sacrifice is therefore about to be performed. Can this be the

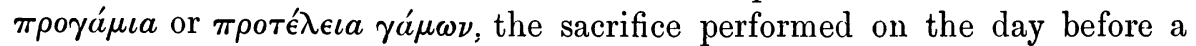
marriage? (cp. Becker-Göll Charikles iii. 361). This representation would be a suitable subject for a Lutrophoros. ${ }^{7}$

On the small fragment we read the letters $L \vee$ retrograde, and by the man's head OLVГIO KA. The latter is of course'O $\lambda v(\mu) \pi \iota o ́[\delta \omega \rho o s] \kappa a[\lambda o ́ s]$, and as there is room for an $\bigcirc$ in the smaller fragment, I should regard the inscription as a repetition of the same love-name. For instances of the dropping of a nasal in vase-inscriptions see Kretschmer Die griechischen Vaseninschriften $\$ 142$. This name is associated with Leagros on the b.f. hydria of the Museo Gregoriano ${ }^{8}$ and the severity and stiffness of this

6 Three branches are similarly held by the priestess on the b.f. amphora with sacrifice to Athena (Berlin 1686).

7 As I have not seen the other fragments of this vase, I fear that what I have conjectured above may prove valueless.

H.S.-VOL. XIV.
8 Surely these are not portraits, as Reisch (Führer II. 247) says. Apart from the fact of the beards, are these figures to be regarded as anything but genre-types? Is the young rider really meant for Leagros on the interior of Euphronios' Geryon kylix? 
vase show its proximity to the b.f. style. The Olympiodoros in question is doubtless the son of Lampon, who commanded a lochos in the Athenian force at Plataea (Hdt. 9, 21) and thus we obtain, it seems to me, a rough date for this vase, as between $510-500$ B.c. It seems to me that Furtwängler's dating (Berl. Phil. Woch. Jan. 20, 1894) is preferable to

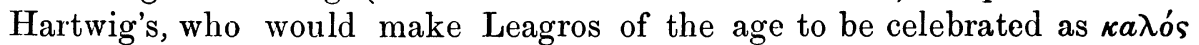
from 500 to 490. If Olympiodoros and Leagros are mentioned together as $\kappa a \lambda o i$, and both occur on r.f. and b.f. works, they must have been approximately of the same age : and quite apart from considerations as to Leagros, the later date makes Olympiodoros younger at Plataea than we should expect; and if, as is probable, his son again was the Lampon who was one of the founders of Thurii, the earlier date better suits the age of Lampon the second.

v.-Pl. III. 2. Pyxis with scenes from female life. A continuous frieze depicting life in the Gynaikonitis is here presented, the drawing being on a small scale and of extreme beauty and delicacy. Two female figures, one seated and one standing, are completely preserved, and portions of four others. All are clad in identically the same garments, in Ionic chiton and overdress thrown over it in various ways. In the centre on a $\delta i \phi \rho o s$

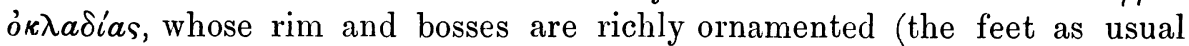
are in the shape of beasts' claws turned inwards), sits a woman to left, in long-sleeved chiton, with himation wrapped loosely round the lower part of her body, her hair bound with a long purple fillet; she stretches out her arms towards the woman approaching from the left, of whom one foot only and part of the chiton are preserved, apparently rather to receive an object from than to offer one to her neighbour. It was no doubt a box containing articles for the toilet. Above in the field are the letters LE i.e. $\kappa a] \lambda \eta{ }^{\prime}$. Behind, a purple fillet hangs on the wall and vertically written is NAVSISTPA $[\tau a$, no doubt her name. The kindred male name Nausistratos occurs on the lip of a lekythos fragment in the Ashmolean Museum at Oxford. Behind the seat is a cock, drawn in a very natural manner, with ample use of purple for the comb, tail and inner markings. Behind, a female figure with similar head-gear and dress, only that the dress is drawn over her left shoulder, advances to right, holding in her right a long stylized flower and in her left a spindle with clew of wool and whorl (purple and black). Before her is a simple stool with cushion, towards which another woman advances holding out a mirror in her right. Between them in the field vertically written is ELITA, in front of which is a break, so that M]e $\lambda_{i} \tau a$ is probably the name meant, and above is $k A\left[\lambda \eta^{\prime}\right]$. The name "E $\mathrm{\lambda} \iota \tau \tau a$ is not impossible ("E $\lambda \iota \sigma a$ was a river in Elis), but Melite is a Nereid's name in Iliad xviii. 42, and as such frequently seen in vases in which Nereids play a part, and as the names of Nereids were particularly favoured for scenes from female life (cp. the r.f. pyxis of the British Museum, Dumont et Chaplain, Cér. de la Grèce Propre Pl. IX.) there is no doubt this is the right reading here. To the extreme right are the tail and foot of another cock. On the other side of the central pair are portions of another pair 
and a swan between them. Only enough of the figures remains to show that their attire was similar to that of the other four women. One holds a long taenia (purple) the two ends of which hang down and show an inscription in white letters $O \triangle A M A S k A(\lambda) O S$ and $k A\left[\lambda o^{\prime} s\right]$. The only uncertain letter is the first, which does not altogether look like an $\bigcirc$ and might be an ornamental mark. The love-name Damas occurs with that of Chairestratos

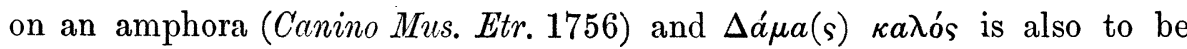
found on the Alkaios and Sappho vase of Munich. But on the whole I am

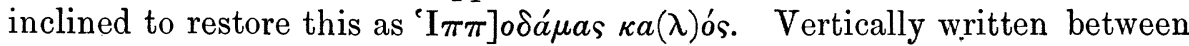
the two is MAKP, which Reisch (Zeitschr. für österr. Gymn. 1887, p. 46)

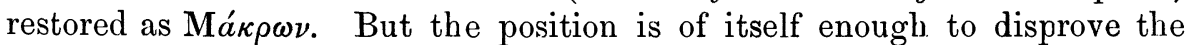
view that this was an artist's signature, and to the style of Makron's vase this pyxis shows no resemblance. It is undoubtedly another female name:

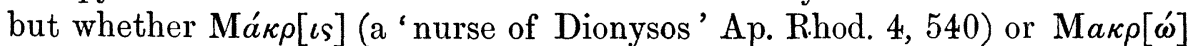

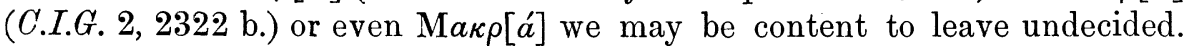
The name Hippodamas suggests the author of the vase, but even without that guide one cannot help comparing the interior of a fragmentary kylix from the Acropolis with the same name (Jahrb. 1887, p. 164), which is undoubtedly the work of Hiero, not of Duris, who prefers to write the name with one $\Gamma$ while Hiero doubles the letter. We may compare the attitude of the woman here, who is walking to right, with that of this lyre-playing boy. The drapery, in the hoop-like manner in which it encircles the waist of the seated woman here, resembles the arrangement of the himation on the boy's shoulder. Finally, the type of face here, with the short upper and projecting under lip and strong chin, is exactly the somewhat sensuous type so characteristic of Hiero. Cocks do not occur in the scenes from the Gynaikonitis so often as other animals, but ducks, geese and swans seem to have been favourite

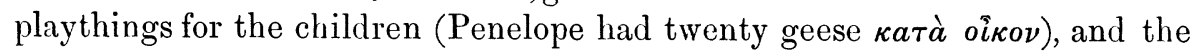
practice of keeping such domestic pets was common at Athens (Stephani, Comptes Rendus 1863, p. 51). For a similar inscription on a taenia, only in red letters on white, see the Louvre fragments of Apollodoros in Hartwig's

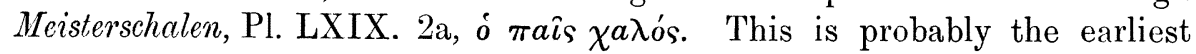
extant specimen of these pyxides with scenes of female life. It is probable that the class was in demand for the purpose of presents after marriage or

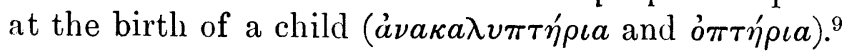

vi.-vii.-Pl. IV. 2 and 3. Finally, we have two fragments of the finest free r.f. style. (a) Part of a large flat lid of a vase, to which other fragments have since been added. ${ }^{10}$ Athena stands in graceful attitude by her olivetree, on which she lays her right hand and towards which she looks. The

9 See Paus. ap. Eust. on Il. xxiv. $29 \epsilon i \tilde{\tau} \alpha$

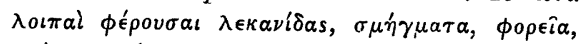

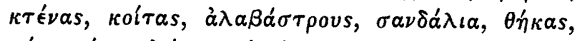

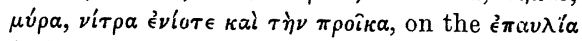

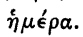

${ }_{10}$ These other fragments are mostly from the edge, so that very scanty portions of the figures are preserved. The lower half of the body is preserved, Dr. Wolters tells me, of one man in chiton and tall laced boots in rapid motion to right. Can this be Dionysos as in the hydria from Kertsch, and is the subject after all the contest of Athena and Paseidon? 
weight of the body rests on the right leg, and the left becomes visible under the chiton, which is girt and has a long' kolpos. In her uplifted right hand she holds a spear. She wears the Corinthian helmet raised, and with long plume, and an aegis of the collarette shape. Spots of dark colour on the edge of the plume and borders of the aegis originally bore added white pigment, with which the fruit of the olive-tree was also rendered. On her arms are bracelets. It is natural to inquire whether in this figure we have a free representation of any of the statues on the Acropolis, but difficult to give any satisfactory answer. The attitude will not suit the Athena of the west pediment of the Parthenon, while the resemblance to the Parthenos is practically nil : nor can it be held that this is a reminiscence of the Lemnia. The inscription on the field is also difficult to restore. EVE $[\mu] \Gamma \bigcirc[\rho o s]$ is probably the name of dedicator or artist, and in the third line the fragmentary letter looks like $\pi$ or $\rho$. It may be $\dot{\epsilon} \pi[o i \eta \sigma \epsilon v]$. It would be too daring to

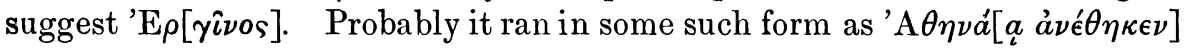

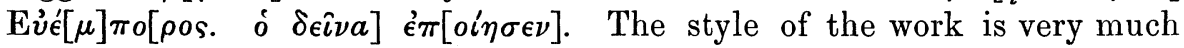
like that of the Kodros-vase, which one would suppose to be of exactly the same period. The name of Mikion is preserved on several Acropolis fragments as a painter of this period, but of course he was only one among many.

(b) This kylix fragment is remarkable for its very fine drawing. A bearded warrior stands to left, with outstretched right hand, which perhaps held a patera, a himation round his waist and sword in sheath at his side suspended by a cord that passes over the right shoulder. The letters $\mid \Gamma$ retrograde in the field are apparently a part of his name, but I am unable to offer any suggestion as to their completion. The helmeted head is a beautiful piece of drawing. The fore part of the helmet is in the shape of the snout of an animal (boar?) with the eye shown. Above that is a purple wreath from which springs a large decorative leaf. The part that covers the head is rendered in a careful trellis pattern. The eye is in profile and some locks of hair escape from beneath the helmet. The anatomy is also noteworthy. Not only the linea alba but the linea semi-lunaris are delicately rendered with a double line, as is the groove of the elbow. The intersection of the linea alba with the upper transverse line of the rectus muscle forms a sort of closed diamond. Antaios on the krater of Euphronios shows an approximation to this in the meeting of double lines. The double drawing of the supra-umbilical linea alba, as in the Peirithoos of the Berlin Centauromachy fragments $(A . Z .1888,17)$ or in the kylikes of Aristophanes, has been pointed to as a stylistic indication of later date, though it is already found in Euphronios. The more thorough use of the double line as here is a safer indication however of the later r.f. period. In the field we read - $\epsilon \nu o s-\epsilon v \sigma \epsilon$. The first word is doubtless one of the names ending in $-\xi \in \nu o s$, but which one cannot say. Pistoxenos suggests itself, but this vase cannot have anything to do with a potter who is associated with Epiktetos and Duris, apart from the fact that he only signs with éroin $\sigma \epsilon \nu$. The other word seems to have been $\left.\epsilon_{\kappa \epsilon} \rho a^{\prime} \mu\right] \epsilon v \sigma \epsilon$. It seems very strange to find it here on a r.f. 
kylix of fine style, but what other restoration is possible, all the letters being certain? After all we have only an insignificant proportion of the output of Greek vase-painters preserved to us, and so are often confronted with apparent idiosyncrasies.

The fragments here published are of absorbing interest and the illustrations will be of value to all who read the forthcoming publication of Dr. Wolters and Dr. Graef and see these works treated in a wider context. To the appearance of the important results of their laborious investigations the archaeological world is looking forward with great anxiety.

\section{G. C. RICHARDS.}

Note.-My attention has been called to the fact that Studniczka (Jahrbuch ii. 154) regards the fragments published in Vol. xiii. of this Journal Pl. XII. as certainly Chalkidian, which I was not aware of at the time when I published them. As Kretschmer points out (Die griech. Vaseninschriften p. 69), the inscriptions give no support to this hypothesis, which must rest on considerations of style only. Pending the appearance of Dr. Loeschcke's work, it is somewhat hazardous to dogmatize on these matters ; but I see no sufficient reason for departing from the view expressed by me, that these fragments show Corinthian influence but are Attic in origin. Dr. Kretschmer ( $i b i d$.) reads the peculiar inscription of this vase as $\Phi \iota \lambda$ ó $\beta \omega \nu$,

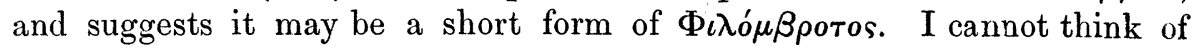
any exact parallel, but his authority is a high one on matters of this kind. 

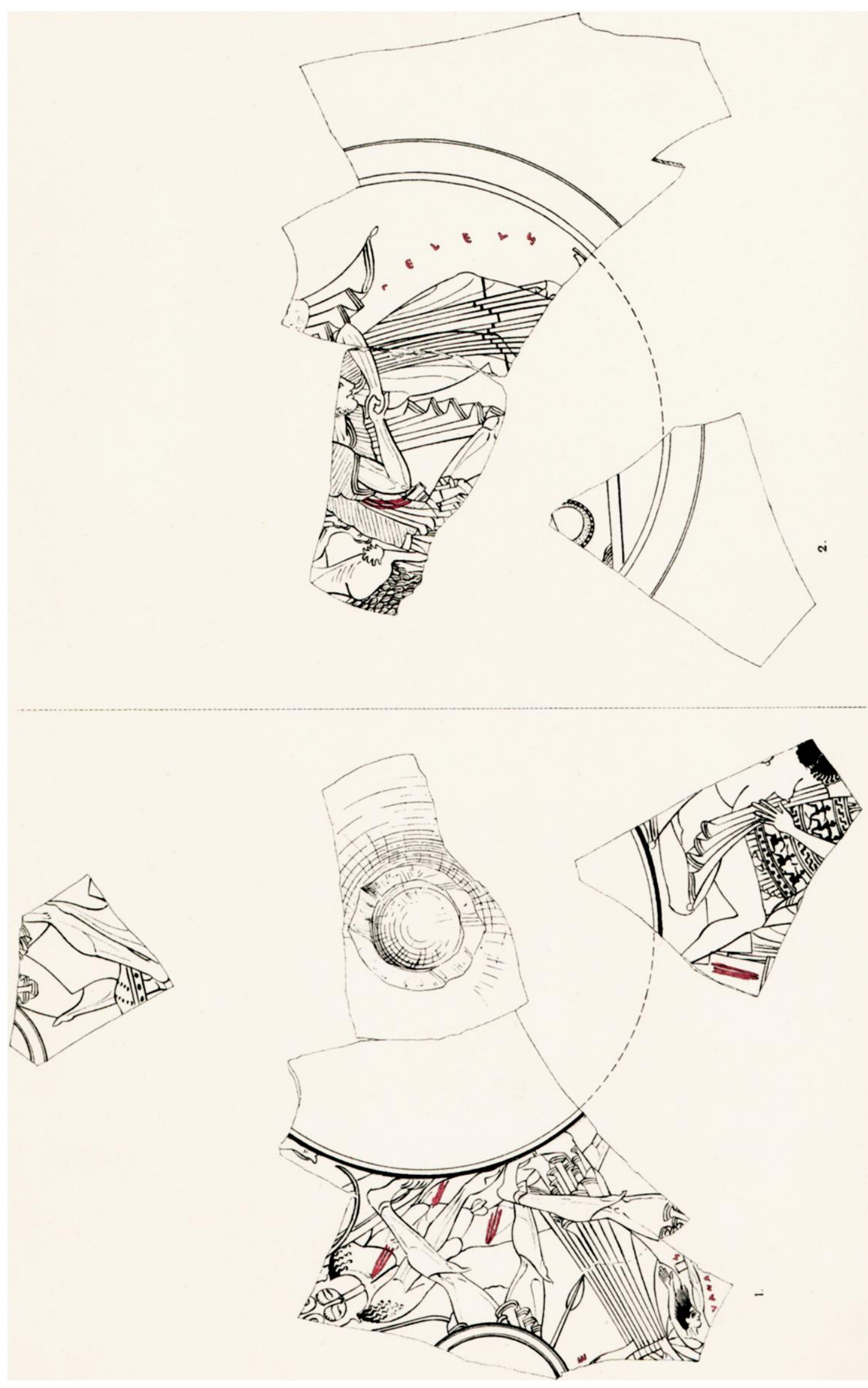

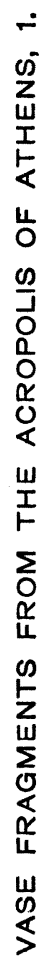



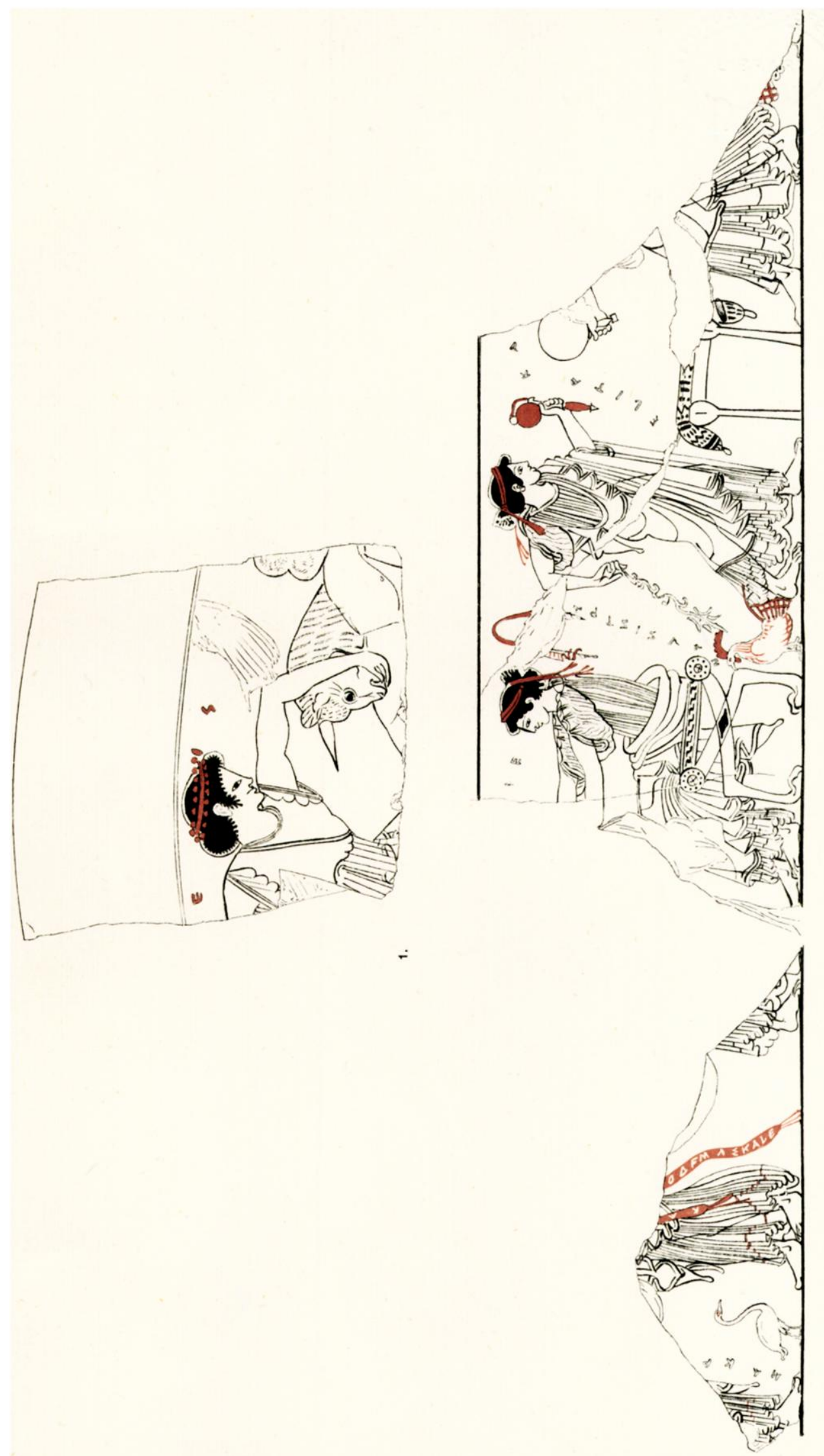

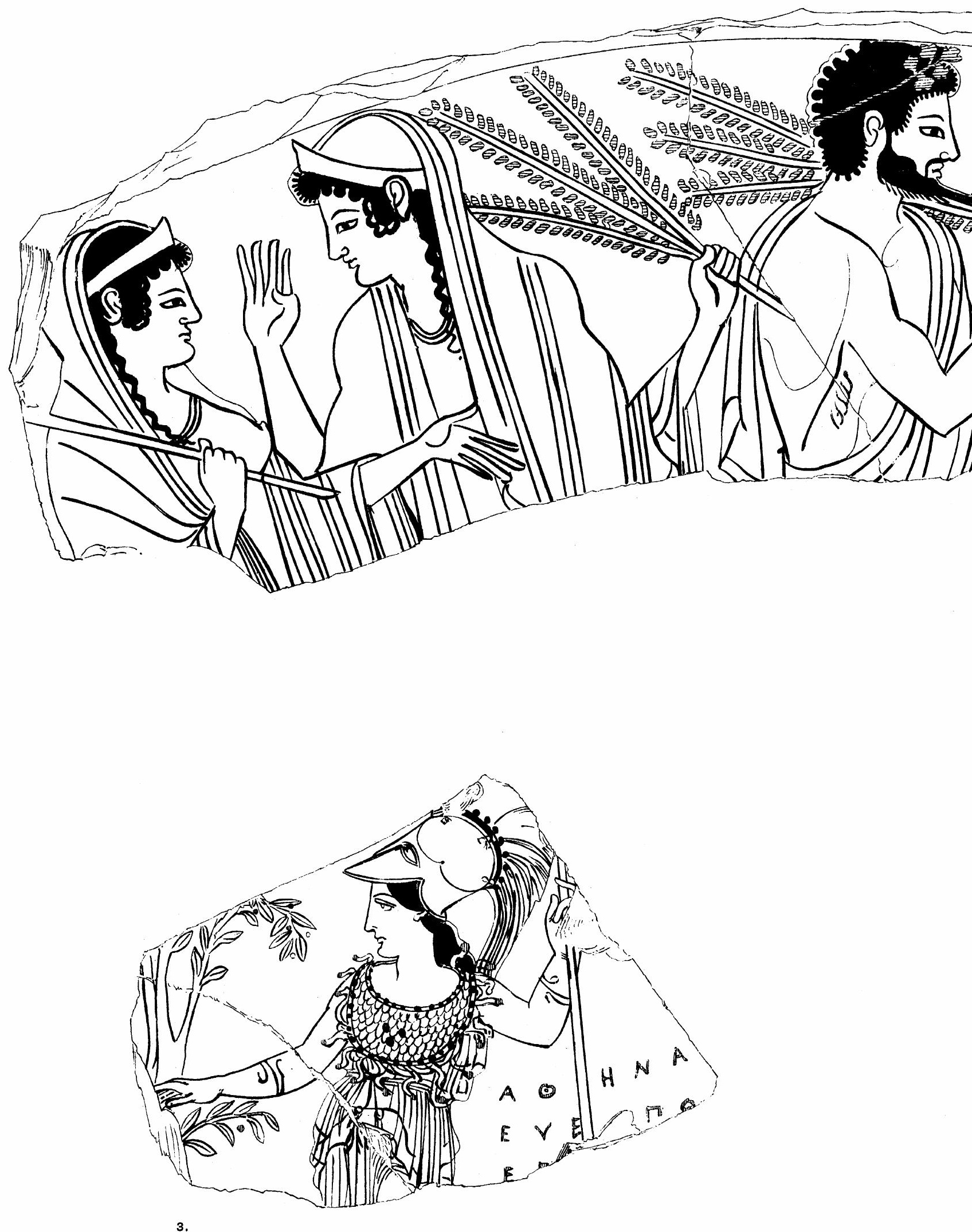

VASE FRAGMENTS FROM THE ACRO 

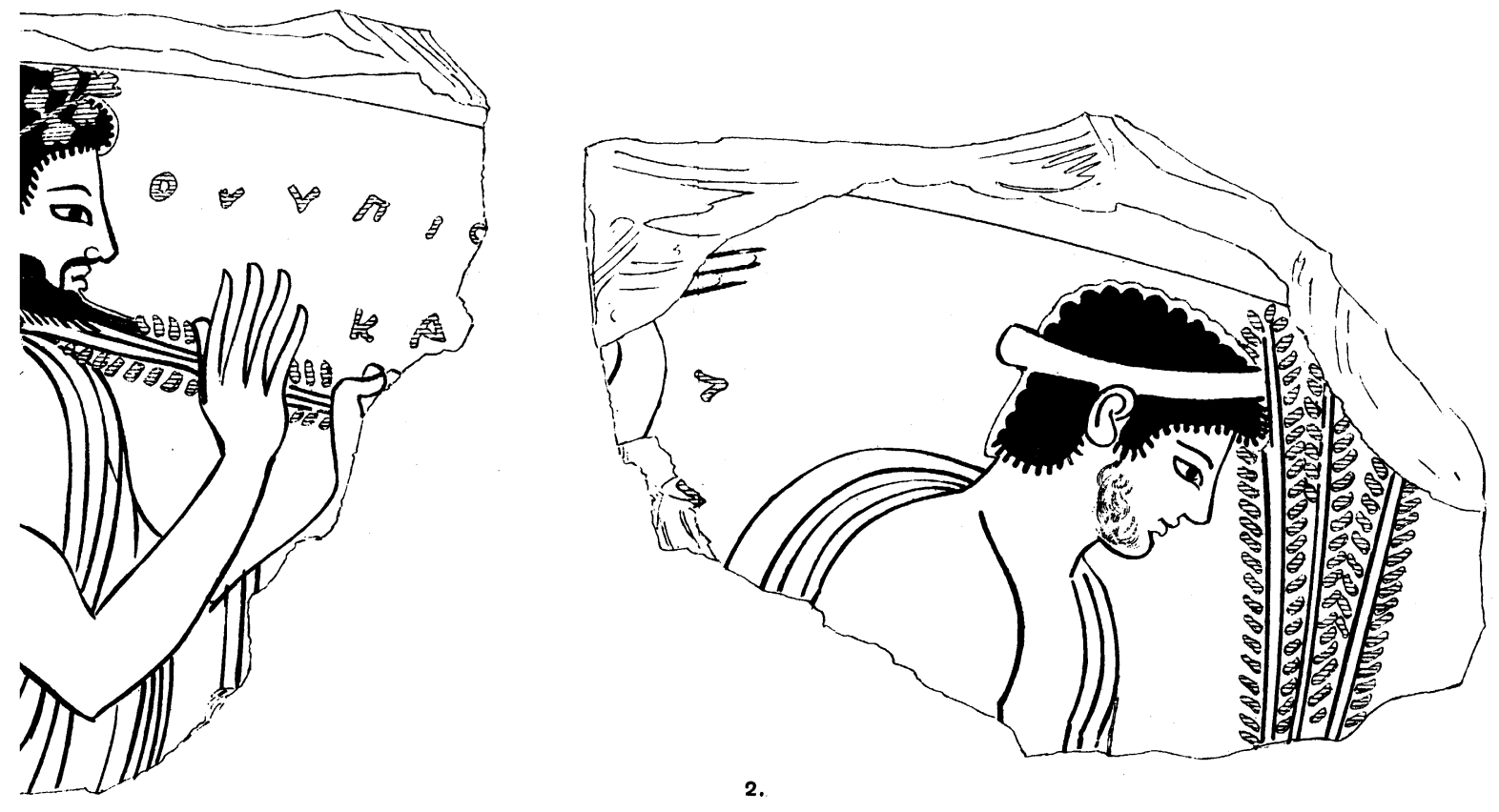

2.

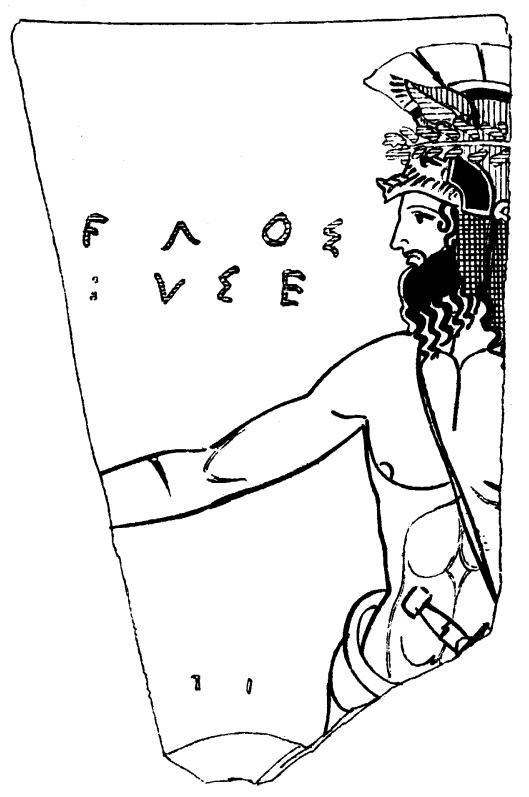

4.

E ACROPOLIS OF ATHENS, 3. 